\title{
Utility Values Associated with Osteoporotic Fracture: A Systematic Review of the Literature
}

\section{Mickaël Hiligsmann · Olivier Ethgen · \\ Florent Richy $\cdot$ Jean-Yves Reginster}

Published online: 22 May 2008

(C) Springer Science+Business Media, LLC 2008

\section{Erratum to: Calcif Tissue Int}

\section{DOI 10.1007/s00223-008-9117-6}

In the above-mentioned article, published in the April issue (vol 82/no 4, 2008, pp 288-292), Dr. Florent Richy's affiliation was listed incorrectly. Please note the correct affiliation below:

Healthcare Outcomes and Pharmaco Epidemiology, UCB, Braine-l'Alleud, Belgium.

The online version of the original article can be found under doi:10.1007/s00223-008-9117-6.

M. Hiligsmann $(\varangle) \cdot$ O. Ethgen · J.-Y. Reginster

Department of Epidemiology, Public Health, and Health

Economics, University of Liege, Avenue de l'hopital, Bat B23, 4000 Liege, Belgium

e-mail: m.hiligsmann@ulg.ac.be

M. Hiligsmann

Department of Economics, University of Liege, Liege, Belgium

F. Richy

Healthcare Outcomes and Pharmaco Epidemiology, UCB,

Braine-l'Alleud, Belgium 